\title{
BUDAYA BERWIRAUSAHA PEREMPUAN MINANGKABAU
}

\author{
Oleh: \\ Armiati \\ Fakultas Ekonomi Universitas Negeri Padang \\ e-mail:armiati@fe.unp.ac.id
}

\begin{abstract}
ABSTRAK
Tingginya partisipasi perempuan dalam kegiatan ekonomi di Sumatera Barat salah satunya disebabkan sistem kekerabatan yang dianut, yaitu sistem matrilineal. Sentralisasi peranan perempuan Minang tidak hanya terbatas pada pendidikan anak, tetapi juga pada pemenuhan kebutuhan ekonomi keluarga melalui penguasaan bendabenda ekonomi atau melalui kegiatan berwirausaha. Dorongan berwirausaha tersebut semakin kuat bila terdapat suami yang pergi merantau untuk memenuhi kebutuhan keluarga. Oleh karenanya, saat ini cukup banyak ditemukan perempuan Minangkabau yang menjadi wirausahawan. Di tengah-tengah kesulitan yang dialami perempuan Minangkabau dalam berwirausaha, tak sedikit dari mereka yang berhasil dan sukses dalam usahanya.
\end{abstract}

Kata kunci: budaya berwirausaha, perempuan minangkabau.

\section{PENDAHULUAN}

Di Indonesia seperti halnya di negara-negara berkembang lainnya, perkembangan kewirausahaan di dalam kelompok perempuan sangat berpotensi sebagai motor utama pendorong proses pemberdayaan perempuan dan transformasi sosial, yang pada akhirnya bisa sangat berdampak positif terhadap penurunan tingkat kemiskinan. Namun demikian, tidak hanya di Indonesia tetapi juga di banyak negara berkembang lainnya, terutama di negara-negara yang pembangunan ekonominya masih belum maju, yang direfleksikan oleh tingkat pendapatan per kapita dan derajat dari industrialisasi yang masih relatif rendah, potensi yang dimiliki perempuan tersebut masih belum terealisasi sepenuhnya. Hal ini berbeda dengan di negaranegara maju yang perkembangan perempuan pengusaha sudah jauh lebih maju. Sinhal (2005), misalnya, menemukan kurang dari 10 persen dari jumlah pengusaha di negara-negara di wilayah Asia Selatan, yang mencakup Bangladesh, Bhutan, India, Maldives, Nepal, Pakistan dan Sri Lanka, adalah perempuan, dan jumlah ini tentu sangat kecil dibandingkan yang yang telah dicapai di negara-negara maju yang persentasenya jauh di atas 10 persen.

Keterlibatan perempuan untuk berwirausaha tidak terlepas dari kajian tentang women entrepreneur. Lahirnya perempuan sebagai wirausahawan atau entrepreneur telah menjadi salah satu kajian yang menarik untuk terus dilakukan karena studi tentang ini masih relatif terbatas. Sejalan dengan pendapat Parker (2010) bahwa few studies have attempted to categorize the literature in a succinct way that focuses on 
the big-picture of female entrepreneurship. Studi tentang women entrepreneurs telah dimulai sejak akhir 1970 an saat jumlah tenaga profesional wanita tumbuh semakin banyak jumlahnya.

Mengapa para perempuan termasuk perempuan Minangkabau mau dan memilih untuk berwirausaha merupakan pertanyaan yang masih menarik untuk dijawab. Padahal kodratnya perempuan diciptakan sebagai pendamping suami untuk mengurus rumah tangga. Studi yang lebih spesifik telah dilakukan oleh banyak peneliti. Beberapa peneliti menyimpulkan bahwa faktor yang mendorong perempuan untuk berwirausaha adalah keinginan untuk menyeimbangkan kehidupan pribadi, karir dan keluarga (Scott, 1986; Kaplin, 1988; Buttner, 1993; Parasuraman, Purohit, Godshalk, \& Beutell, 1996). Penelitian Hisrich (dalam Raman, 2008) mengungkapkan bahwa terdapat perbedaan faktor yang memotivasi perempuan dan laki-laki untuk berwirausaha. Laki-laki berwirausaha karena adanya ketidakcocokan dengan bos dan dorongan untuk memiliki kebebasan dalam menentukan nasib sendiri. Sementara perempuan berwirausaha karena adanya kekecewaan dalam pekerjaan dimana mereka tidak diberikan kesempatan untuk mengaktualisasikan diri sesuai dengan kemampuan yang dimiliki. Jadi perempuan berwirausaha karena keinginan untuk bebas dan berprestasi.

Tak terkecali di Sumatera Barat sendiri, banyak ditemukan perempuan Minangkabau yang menjadi pengusaha. Mulai dari usaha kecil sampai kepada usaha yang telah maju dan besar. Dalam kajian women entrepreneurs Minangkabau, unsur budaya Minangkabau muncul dan menjadi alasan mengapa banyak masyarakat Minangkabau yang terkenal sebagai pebisnis yang handal. Beberapa unsur budaya Minangkabau yang diduga memiliki kontribusi terhadap lahirnya women entrepreneurs di Minangkabau yaitu sistem kekerabatan yang matrilineal, budaya marantau dan budaya berdagang orang Minangkabau. Hal ini senada dengan yang dikemukakan oleh Taner (dalam Miko, 1991) yang menyatakan bahwa tingginya partisipasi perempuan dalam kegiatan ekonomi di Sumatera Barat salah satunya disebabkan sistem kekerabatan yang dianut, yaitu sistem matrilineal. Sentralisasi peranan perempuan Minang tidak hanya terbatas pada pendidikan anak, tetapi juga pada pemenuhan kebutuhan ekonomi keluarga melalui penguasaan benda-benda ekonomi.

\section{KONSEP DAN TEORI KEWIRAUSAHAAN}

Pada abad ke-17 istilah entrepreneur digambarkan sebagai orang yang melakukan kontrak pekerjaan dengan pemerintah untuk memasok produk tertentu. Kontrak ini memakai harga tetap, keuntungan atau kerugian yang diperoleh dari pekerjaan ini adalah merupakan imbalan dari kegiatan wirausaha. Kata "wirausaha" merupakan gabungan kata wira (= gagah berani, perkasa) dan usaha. Jadi, wirausaha berarti orang yang gagah berani atau perkasa dalam usaha. Sedangkan kata "wiraswasta" terdiri dari kata wira (= gagah berani, perkasa) dan swa (= sendiri, mandiri). Jadi, wiraswasta berarti orang yang perkasa dan mandiri (Alma, 2009).

Dalam berbagai referensi, kita menemukan rumusan yang dikemukakan para pakar manajemen dan psikologi tentang wirausaha atau entrepreneur. Zimmerer (1996) mengemukakan bahwa wirausahawan adalah seseorang yang menciptakan sebuah bisnis baru dengan mengambil resiko dan ketidakpastian demi mencapai keuntungan dan pertumbuhan dengan cara mengidentifikasi peluang dan penggabungan sumber daya yang diperlukan untuk mendirikannya. 
Selanjutnya menurut Riyanti (2003) "Wirausaha adalah orang yang menciptakan kerja bagi orang lain dengan cara mendirikan, mengembangkan, dan melembagakan perusahaan miliknya sendiri dan bersedia mengambil risiko pribadi dalam menemukan peluang berusaha dan secara kreatif menggunakan potensipotensi dirinya untuk mengenali produk, mengelola dan menentukan cara produksi, menyusun operasi untuk pengadaan produk, memasarkannya serta mengatur permodalan operasinya".

Untuk menjadi seorang wirausaha yang sukses, Murphy and Peck dalam Alma (2009) menggambarkan delapan anak tangga untuk mencapai puncak karir. Delapan anak tangga tersebut adalah: a) mau kerja keras, b) bekerjasama dengan orang lain, c) penampilan yang baik, d) memiliki keyakinan diri, e) pandai membuat keputusan, f) mau menambah ilmu pengetahuan, g) ambisi untuk maju, dan h) pandai berkomunikasi.

Wirausaha merupakan potensi pembangunan, baik dalam jumlah maupun dalam mutu wirausaha itu sendiri. Alma (2009) memaparkan manfaat adanya wirausaha adalah sebagai berikut:

a) Menambah daya tampung tenaga kerja, sehingga dapat mengurangi pengangguran.

b) Sebagai generator pembangunan lingkungan, bidang produksi, distribusi, pemeliharaan lingkungan, kesejahteraan, dan sebagainya.

c) Menjadi contoh anggota masyarakat lain, sebagai pribadi unggul yang patut dicontoh, diteladani, karena seorang wirausaha itu adalah orang terpuji, jujur berani, hidup tidak merugikan orang lain.

d) Selalu menghormati hukum dan peraturan yang berlaku, berusaha selalu menjaga dan membangun lingkungan.

e) Berusaha memberi bantuan kepada orang lain dan pembangunan sosial sesuai dengan kemampuannya.

f) Berusaha mendidik karyawannya menjadi orang mandiri, disiplin, jujur, tekun dalam menghadapi pekerjaan.

g) Memberi contoh bagaimana kita harus bekerja keras, tetapi tidak melupakan perintah-perintah agama, dekat kepada Allah SWT.

h) Hidup secara efisien, tidak berfoya-foya dan tidak boros.

i) Memelihara keserasian lingkungan, baik dalam pergaulan maupun kebersihan lingkungan.

Berdasarkan uraian di atas dapat diketahui bahwa sangat besar manfaat yang dapat diberikan oleh wirausaha terhadap pembangunan bangsa.

\section{Faktor-faktor yang Mempengaruhi Kewirausahaan}

Faktor-faktor yang mempengaruhi kewirausahaan dapat dibagi menjadi dua yaitu faktor internal dan eksternal. Faktor internal merupakan faktor dari dalam individu itu sendiri sedangkan faktor eksternal merupakan hasil interaksi individu dengan lingkungannya (Suryana, 2001). Faktor-faktor yang mempengaruhi kewirausahaan antara lain:

a. Faktor internal, meliputi

1) Kebutuhan berprestasi (need for achievement); kebutuhan berprestasi mendorong individu untuk menghasilkan yang terbaik. Tujuan yang ingin dicapai seorang wirausahawan dipengaruhi oleh kebutuhan akan berprestasinya yang mendorong individu untuk menghasilkan yang terbaik 
dan biasanya memiliki inisiatif serta keinginan yang kuat untuk mengungkapkan ide-ide dalam pikirannya, menyampaikan gagasan demi mencapai suatu kesuksesan. Ide yang dimiliki seorang wirausahawan kadang dipandang aneh dan berbeda dari ide umumnya, maka diperlukan kemampuan individu agar dapat menyampaikan ide-idenya sehingga dapat diterima oleh orang lain dan masyarakat, untuk itulah seorang wirausahawan memerlukan kompetensi sosial.

2) Internal locus of control; dijelaskan lebih lanjut bahwa individu yang memiliki internal locus of control mempercayai bahwa kegagalan dan kesuksesan yang dialami ditentukan dari usaha yang dilakukan. Individu yakin akan kemampuan yang dimiliki dan berusaha keras mencapai tujuannya (Riyanti, 2003).

3) Kebutuhan akan kebebasan (need for independence); seorang wirausahawan diharuskan untuk melakukan sesuatu berdasarkan caranya sendiri, sehingga memiliki kebutuhan akan kebebasan yang tinggi. Kebutuhan akan kebebasan berarti kebutuhan individu untuk mengambil keputusan sendiri, menentukan tujuan sendiri serta melakukan tindakan untuk mencapai tujuan dengan caranya sendiri.

4) Nilai-nilai pribadi; nilai-nilai pribadi sangat penting bagi para wirausahawan (Suryana, 2001). Beberapa penelitian menunjukkan bahwa wirausaha mempunyai sifat dasar mengenai proses manajemen dan bisnis secara umum yang membantu individu menciptakan dan mempertahankan bisnis yang dirintis. Sifat dasar meliputi nilai kemenangan bagi individu yang berarti berhasil mengaktualisasikan dirinya.

5) Pengalaman; diartikan sebagai pengalaman kerja individu sebelum memutuskan kewirausahaan sebagai pilihan karir. Pengalaman kerja mempengaruhi individu dalam menyusun rencana dan melakukan langkahlangkah selanjutnya. Penelitian Kim (Riyanti, 2003) menunjukkan bahwa pengalaman memberikan pengaruh terhadap keberhasilan usaha.

b. Faktor eksternal, meliputi

1) Role model; merupakan faktor penting yang mempengaruhi individu dalam memilih kewirausahaan sebagai karir. Orang tua, saudara, guru atau wirausahawan lain dapat menjadi role model bagi individu. Individu membutuhkan dukungan dan nasehat dalam setiap tahapan dalam merintis usaha, role model berperan sebagai mentor bagi individu. Individu juga akan meniru perilaku yang dimunculkan oleh role model. Pentingnya role model dalam mempengaruhi pilihan karir didukung oleh penelitian Jacobowitz dan Vidler (Riyanti, 2003) yang menunjukkan bahwa $72 \%$ wirausahawan negara Atlantik memiliki orang tua atau saudara wirausahawan. Individu berwirausaha dengan cara meniru orang tua atau saudara yang berwirausaha.

2) Dukungan keluarga dan teman; dukungan dari orang dekat akan mempermudah individu sekaligus menjadi sumber kekuatan ketika menghadapi permasalahan. Dukungan dari lingkungan terdekat akan membuat individu mampu bertahan menghadapi permasalahan yang terjadi.

3) Pendidikan; pendidikan formal berperan penting dalam kewirausahaan karena memberi bekal pengetahuan yang dibutuhkan dalam mengelola usaha terutama ketika menghadapi suatu permasalahan. Sekolah atau Universitas sebagai tempat berlangsungnya pendidikan formal yang mendukung 
kewirausahaan akan mendorong individu untuk menjadi seorang wirausahawan.

Berdasarkan pendapat para ahli maka dapat disimpulkan bahwa faktor yang mempengaruhi kewirausahaan ada dua, yakni faktor internal yang merupakan faktor dari dalam diri individu dan faktor eksternal yang merupakan hasil interaksi individu dengan lingkungannya. Faktor internal meliputi kebutuhan berprestasi, internal locus of control, kebutuhan akan kebebasan, nilai-nilai pribadi, dan pengalaman, sedangkan faktor eksternal meliputi role model, dukungan keluarga dan teman, serta pendidikan.

Sementara itu, menurut Suryana (2003) dilihat dari ruang lingkupnya wirausaha memiliki dua fungsi, yaitu fungsi makro dan fungsi mikro. Secara makro, wirausaha berperan sebagai penggerak pengendali dan pemacu perekonomian suatu bangsa. Sedangkan secara mikro, peran wirausaha adalah penanggung resiko dan ketidakpastian, mengombinasikan sumber-sumber ke dalam cara yang baru dan berbeda untuk menciptakan nilai tambah dan usaha-usaha baru.

Dalam melakukan fungsi mikronya, menurut Marzuki Usman (dalam Suryana, 2003), secara umum wirausaha memiliki dua peran, yaitu:

1. Sebagai penemu (innovator)

Sebagai innovator wirausaha berperan dalam menemukan dan menciptakan:
a. Produk baru (the new product)
b. Teknologi baru (the new technology)
c. Ide-ide baru (the new image)
d. Organisasi usaha baru (the new organization)

2. Sebagai perencana (planner)

Sebagai planner wirausaha berperan dalam merancang:

a. Perencanaan perusahaan (corporate plan)

b. Strategi perusahaan (corporate strategy)

c. Ide-ide dalam perusahaan (corporate image)

d. Organisasi perusahaan (corporate organization)

Menurut Zimmerer (dalam Suryana, 2003) fungsi wirausaha adalah menciptakan nilai barang dan jasa di pasar melalui proses pengkombinasian sumber daya dengan cara-cara baru berbeda untuk dapat bersaing.

\section{Berbagai Macam Profil Wirausaha}

Menurut Zimmerer dan Scarborough (2002), jika diperhatikan entrepreneur yang ada di masyarakat sekarang ini, maka dijumpai berbagai macam profil yaitu:

1. Women Entrepreneur

Banyak wanita yang terjun ke dalam bidang bisnis. Alasan mereka menekuni bidang bisnis ini didorong oleh faktor-faktor antara lain ingin memperlihatkan kemampuan prestasinya, membantu ekonomi rumah tangga, frustasi terhadap pekerjaan sebelumnya dan sebagainya.

2. Minority Entrepreneur

Kaum minoritas terutama di negara kita Indonesia kurang memiliki kesempatan kerja di lapangan pemerintahan sebagaimana layaknya warga negara pada umumnya. Oleh sebab itu, mereka berusaha menekuni kegiatan bisnis dalam kehidupan sehari-hari. Demikian pula para perantau dari daerah tertentu yang menjadi kelompok minoritas pada suatu daerah, mereka juga berniat 
mengembangkan bisnis. Kegiatan bisnis mereka ini makin lama makin maju, dan mereka membentuk organisasi minoritas di kota-kota tertentu.

3. Immigrant Entrepreneurs

Kaum pedagang yang memasuki suatu daerah biasanya sulit untuk memperoleh pekerjaan formal. Oleh sebab itu, mereka lebih leluasa terjun dalam pekerjaan yang bersikap non-formal yang dimulai dari berdagang kecil-kecilan sampai berkembang menjadi perdagangan tingkat menengah.

4. Part Time Entrepreneurs

Memulai bisnis dalam mengisi waktu lowong atau part-time merupakan pintu gerbang untuk berkembang menjadi usaha besar. Bekerja part-time tidak mengorbankan pekerjaan di bidang lain misalnya seorang pegawai pada sebuah kantor mencoba mengembangkan hobinya untuk berdagang atau mengembangkan suatu hobi yang menarik. Hobi ini akhirnya mendatangkan keuntungan yang lumayan. Ada kalanya orang ini beralih profesi, dan berhenti menjadi pegawai dan beralih ke bisnis yang merupakan hobinya.

5. Home-Based Entrepreneurs

Ada pula ibu-ibu rumah tangga yang memulai kegiatan bisnisnya dari rumah tangga misalnya ibu-ibu yang pandai membuat kue dan aneka masakan, mengirim kue-kue ke toko eceran di sekitar tempatnya. Akhirnya usaha makin lama makin maju. Usaha catering banyak dimulai dari rumah tangga yang bisa masak. Kemudian usaha ini berkembang melayani pesanan untuk pesta.

6. Family-Owned Business

Sebuah keluarga dapat memulai membuka berbagai jenis cabang dan usaha. Mungkin saja usaha keluarga ini dimulai lebih dulu oleh bapak setelah usaha bapak ini maju dibuka cabang baru dan dikelola oleh ibu. Kedua perusahaan ini maju dan membuka beberapa cabang lain mungkin jenis usahanya berbeda atau lokasinya berbeda. Masing-masing usahanya ini bisa dikembangkan atau dipimpin oleh anak-anak mereka. Dalam keadaan sulitnya lapangan kerja pada saat ini maka kegiatan semacam ini perlu dikembangkan.

7. Copreneurs

Copreneurs are entrepreneurial couples who work together as co-ownners of their businesses. (Copreneurs adalah pasangan wirausaha yang bekerja bersamasama sebagai pemilik bersama dari usaha mereka). Copreneurs ini berbeda dengan usaha keluarga yang disebut sebagai usaha Mom and Pop (Pop as "boss" and Mom as "subordinate" / Ayah sebagai pemimpin dan Ibu berada di bawah kekuasaan Ayah).

Copreneurs dibuat dengan cara menciptakan pembagian pekerjaan yang didasarkan atas keahlian masing-masing orang. Orang-orang yang ahli di bidang ini diangkat menjadi penanggung jawab divisi-divisi tertentu dari bisnis-bisnis yang sudah ada.

\section{PEREMPUAN DAN BUDAYA MINANGKABAU}

Orang Minangkabau menghitung garis keturunannya berdasarkan garis keturunan ibu. Masyarakat Minangkabau menganut sistem matrilineal. Matrilineal berasal dari dua kata, yaitu "matri" yang artinya ibu dan "lineal" artinya garis. Jadi matrilineal mengandung pengertian menarik keturunan menurut garis ibu (Maharajo, 2011). Dalam sistem kekerabatan ini garis keturunan mengikut keturunan ibu. Anak akan menjadi anggota kerabat ibunya dan memperolehi persukuan ibu. Dalam 
literatur tentang kemasyarakatan dinyatakan bahawa sistem kekerabatan matrilineal yang terbesar di dunia adalah Minangkabau.

Menurut Abidin (2008), pada dasarnya sistem matrilineal bukanlah untuk mengangkat atau memperkuat peranan perempuan, tetapi sistem itu dikukuhkan untuk menjaga, melindungi harta pusaka suatu kaum dari kepunahan, baik rumah gadang, tanah pusaka dan sawah ladang. Sementara itu sebagian dari individu lakilaki Minang kecenderungan mereka akan pergi merantau untuk mencari penghidupan demi dirinya dan keluarganya.

Dalam masyarakat Minangkabau di Sumatera Barat, ada dua unsur yang disebut dalam dwi tunggal: mamak dan bundo kanduang. Mamak adalah status yang diberi kepada laki-laki dalam keturunan keluarga ibu. Yang termasuk mamak adalah saudara laki-laki ibu, bapak saudara sebelah ibu, anak laki-laki dari pihak keturunan ibu. Menurut tambo, sejarah Minangkabau, bundo kanduang adalah institusi perempuan. Ia sangat penting. Dalam banyak tulisan, termasuk Tambo Alam Minangkabau yang ditulis Datoek Toeah dalam Hermayulis (2000), bundo kanduang adalah penguasa perempuan yang diertikan sebagai ratu di Minangkabau. Makna bundo adalah ibu dan kanduang, sejati. Jadi, bundo kanduang adalah ibu sejati yang mempunyai sifat keibuan dan kepemimpinan. Pengertian itu menyatakan bahawa perempuan ditempatkan sebagai pemilik sifat kepemimpinan. Peranan bundo kanduang dimainkan setiap perempuan di Minangkabau sehingga ia adalah panggilan kepada perempuan menurut adat Minangkabau..

Sebagai "pengantar" keturunan, perempuan harus menjaga diri dan menempatkan dirinya dalam aturan adat basandi Syara, tahu membedakan antara baik dan buruk, halal dan haram dalam hal makanan, dan banyak lagi perbuatan lahiriah lain. Bundo kanduang dalam masyarakat Minangkabau mempunyai tempat yang mulia, dikenali "pepatah adat" sebagai Bundo kaduang, limpapeh rumah nan gadang, pusek jalo kumpulan tali, sumarak di dalam kampuang, hiasan dalam nagari.

\section{Peranan Perempuan Minangkabau}

Makna peranan adalah bagian yang dimainkan individu, selain tindakannya. Dalam tulisan ini, peranan dimaksudkan sebagai tindakan perempuan dalam masyarakat. Peranan perempuan Minangkabau di Sumatera Barat adalah:

1. Menyimpan Hasil Usaha Ekonomi

Peranan ini disebut dalam adat Minangkabau sebagai umbun puruak pagangan kunci, umbun puruak aluang bunian. Maknanya perempuan berperanan sebagai pemegang kunci (orang yang menyimpan dan menjaga) hasil kegiatan ekonomi anggota keluarga. Peranan itu telah melekat pada perempuan Minangkabau, bahkan sangat terlihat semasa lelaki merantau. Perempuan Minangkabau sudah biasa dengan peranannya sebagai ibu tunggal menjaga anak-anaknya selama suaminya merantau. Dalam masa itu ekonomi keluarga akan menjadi tanggung jawab sepenuh bagi perempuan. Bagi perempuan Minangkabau kondisi ini sudah biasa, karena mereka sudah terlatih membuatnya. Di Kabupaten Agam dan Kota Bukittinggi, banyak sekali perempuan membuat baju, sulaman, baju kurung, kebaya, mukena dan lain-lain dijadikan home industry.

2. Sumarak dalam nagari, hiasan dalam kampung (penyemarak dalam nagari dan hiasan (dekor) dalam kampung. Perempuan akan membuat indah dan semaraknya 
nagari, dalam arti kehidupan dalam nagari. Nagari akan menjadi hidup dan teratur dengan perempuan memainkan berbagai peranan.

3. Nan gadang basa batuah (bertuah)

Perempuan adalah anggota masyarakat yang istimewa karana mempunyai karisma yang disegani dari segi kecerdasan dan kepakarannya yang bukan saja dalam memimpin dan mengayomi keluarga, tetapi juga dalam masyarakat. Mereka akan menjadi pai tampek batanyo, pulang tampek babarito, maknanya pergi tempat bertanya, pulang tempat berberita.

4. Kaunduang-unduang ka Madinah, ka payuang panji ka sarugo (Penutup kepala atau tudung dari panas atau hujan ke Madinah, untuk payung panji ke Syorga). Dalam pepatah di atas, perempuan dinyatakan sudah memainkan peranan sebagai pelindung dan penjaga anggota keluarga, anggota suku atau kaumnya dari perbuatan orang lain dan juga perbuatan dirinya yang bertentangan dengan nilai agama dan adat.

5. Hak suara perempuan dalam musyawarah

Dalam masyarakat Minangkabau, bundo kanduang mempunyai hak dan suara yang sama dengan laki-laki. Semua perkara diputuskan dalam musyawarah dengan melibatkan suku dan kaum, termasuk acara perkawinan. Dalam acara perkawinan, peranan perempuan sangat menentukan dalam arti kata acara perkawinan tidak akan dilaksanakan jika perempuan tidak setuju. Namun, ada tiga pendapat yang bertentangan berkenaan hak dan suara perempuan. Ada yang menyatakan perempuan tidak mempunyainya karana perempuan tidak boleh duduk bersama dengan lelaki dalam musyawarah. Ada pula yang menyatakan perempuan boleh menyuarakan pendapatnya karana mereka boleh menghadiri musyawarah. Selain itu, ada yang menyatakan perempuan boleh menyampaikan pendapat mereka dengan pertolongan orang laki-laki.

Selanjutnya, dalam adat minangkabau dikenal pula dengan adat dan kebiasaan merantau bagi kaum laki-laki. Dari sudut sosiologi, menurut Naim dalam Maharajo (2011) merantau adalah meninggalkan kampung halaman dengan kemauan sendiri untuk jangka waktu lama ataupun tidak dengan tujuan mencari penghidupan, menuntut ilmu, atau mencari pengalaman dan biasanya dengan maksud kembali pulang. Sistem sosio-ekonomi nagari Minangkabau, dengan tradisi merantau, merupakan tradisi yang unik dan cocok untuk mencari peruntungan lewat kesempatan-kesempatan baru. Menurut Graves (2007), keluarga-keluarga yang paling kuat dalam pengembangan tradisi merantau dapat dibedakan ke dalam dua kategori, meskipun keduanya tidak bersifat eksekutif, yaitu: penuntut ilmu agama dan pedagang kecil (atau seni pengrajin). Seperti halnya dengan kebanyakan tradisi Minangkabau umumnya, Maharajo (2011) mengungkapkan bahwa kebiasaan marantau ini disanjung dengan ungkapan pepatah " $k a$ rantau madang di hulu; babuah babungo balun; ka rantau bujang dahulu; dikampung baguno balun".

Beberapa alasan masyarakat Minangkabau pergi merantau juga dikemukakan oleh Maharajo (2011) yaitu (a) alasan ekonomi, (b) alasan pendidikan, (c) alasan sosial, dan (d) alasan kejiwaan. Sebuah hasil penelitian yang dilakukan oleh Bungo dan Nordin (2011) mengungkapkan bahwa kegigihan perantau Minang yang bergiat aktif dalam bidang ekonomi salah satunya terlihat di Kuala Lumpur. Bidang ekonomi yang mereka geluti adalah sektor pertanian, perniagaan, dan perlombongan jelas terlihat dalam sejarah awal Kuala Lumpur. 
Salah satu tujuan orang Minang merantau adalah untuk berdagang. Motivasi orang minang dalam berdagang adalah karena ingin melawan dunia orang, suatu tema yang mengandung amanat untuk hidup bersaing terus menerus mencapai kemuliaan, kenamaan, kepintaran dan kekayaan. Orang Minang berpolakan prinsip bagi hasil pada sistem anak semang dan induk semang. Bagi orang minang, profesi sebagai pedagang, merupakan salah satu diantara aktualisasi peran fungsional dalam mencari nafkah hidup. Menjadi saudagar, adalah suatu cita-cita (Djamaludin, 2008).

Apabila terdapat anggota keluarga di Minangkabau yang pergi merantau, terutama suami, maka kaum perempuan di Minangkabau mempunyai tanggungjawab untuk mengurus keluarga. Mulai dari mengurus keperluan yang kecil, sampai kepada pemenuhan kebutuhan termasuk membantu suami dalam mencari nafkah dengan melakukan kegiatan usaha.

\section{Wirausahawan Perempuan di Minangkabau}

Ada beberapa faktor yang dikemukakan oleh Alma (2009) yang menjadi menghambat perempuan untuk menjadi wirausahawan antara lain :

1. Faktor kewanitaan

Sebagai seorang ibu rumah tangga ada masa hamil dan menyusui sehingga agak mengganggu jalannya bisnis. Hal ini dapat diatasi dengan mendelegasikan wewenang/tugas kepada karyawan/orang lain. Tentunya pendelegasian ini mempunyai keuntungan dan kerugian. Jalannya perusahaan tidak akan persis sama bila dipimpin oleh pemilik sendiri, jadi ada dua kemungkinan, lebih baik atau lebih buruk.

2. Faktor sosial budaya

Wanita sebagai ibu rumah tangga, bertanggung jawab penuh dalam urusan rumah tangga. Bila anak atau suami sakit, ia harus memberikan perhatian penuh, dan ini akan mengganggu aktivitas usahanya. Jalannya bisnis yang dilakukan oleh wanita tidak sebebas yang dilakukan laki-laki. Wanita tidak bebas melakukan perjalanan ke luar kota, acara makan malam dan sebagainya. Begitu juga dengan anggapan dan kebiasaan dalam suatu rumah tangga bahwa suamilah yang memberi nafkah, suami yang bekerja, maka sulit juga suatu usaha berkembang menjadi suatu usaha yang besar.

3. Faktor emosional

Faktor emosional yang dimiliki wanita, disamping menguntungkan juga bisa merugikan. Misalnya dalam pegambilan keputusan, karena ada faktor emosional maka keputusan yang diambil akan kehilangan rasionalitasnya. Juga dalam memimpin karyawan, muncul elemen-elemen emosional yang mempengaruhi hubungan dengan karyawan pria atau wanita yang tidak rasional lagi.

4. Faktor administrasi

Faktor administrasi yang berbelit merupakan satu faktor yang sangat menghambat wanita dalam memulai membuka usaha. Menurut penelitian dari Proyek Peningkatan Peran Usaha Swasta (Private Enterprise Participation Project) tentang wanita pengusaha di Indonesia pada tahun 2003 menyebutkan, fakta bahwa 35\% wanita mengalami kesulitan dalam memperoleh pinjaman.

5. Faktor Pendidikan

Faktor pendidikan merupakan salah satu faktor penghambat wanita berwirausaha. Data yang diperoleh dari Biro Pusat Statistik mengenai tingkat pendidikan yang diperoleh pengusaha profil industri skala kecil dan kerajinan pada 2002 sangat 
mengecewakan karena perbedaan tingkat pendidikan antara wanita dan pria sangat timpang dan didominasi oleh kaum pria. Hal tersebut menjadi salah satu alasan mengapa women entrepreneur sulit berkembang.

Walaupun secara teoritis diketahui terdapat beberapa hambatan bagi perempuan untuk berwirausaha, namun cukup banyak perempuan di Minangkabau yang tetap melakukan kegiatan berwirausaha. Hal ini diketahui dari beberapa penelitian yang pernah dilakukan terkait dengan wirausahawan perempuan Minangkabau ini. Penelitian terkait dengan kegiatan berwirausaha perempuan Minangkabau salah satunya dilakukan oleh Rahmidani, dkk (2012) terhadap pengrajin sulaman wanita di Jorong Lundang Kabupaten Agam. Berdasarkan hasil penelitiannya, ditemukan faktor internal yang mendorong perempuan untuk berwirausaha adalah adanya keinginan di dalam diri mereka untuk berprestasi, sukses, menjadi bos, mendapat penghargaan dan terkenal. Dari segi internal locus of control pengrajin wanita memiliki keinginan untuk maju, berani mengakui kesalahan dan berani untuk mengambil resiko. Untuk faktor kebutuhan akan kebebasan, yang mendorong pengrajin wanita untuk berwirausaha adalah untuk memperoleh kebebasan dalam mencari penghasilan dan keinginan untuk bekerja tanpa di atur oleh orang lain. Dari segi nilai-nilai pribadi terlihat dari penilaian mereka atas diri sendiri bahwa mereka ramah, suka menghadapi tantangan dan suka berdagang. Faktor pengalaman juga terkait dengan pengalaman mereka sebagai karyawan pada bisnis orang lain.

Terkait dengan faktor eksternal berupa role model, dukungan keluarga dan teman serta faktor pendidikan juga diperoleh beberapa temuan dari penelitian tersebut. Pada faktor role model yang mendorong pengrajin wanita untuk berwirausaha adalah orang tua, saudara dan orang lain. Sedangkan dukungan yang diperoleh oleh pengrajin sulaman wanita berasal dari keluarga baik orang tua maupun saudara. Mereka terlihat belum merasakan dukungan yang berarti dari teman. Sementara faktor pendidikan yang mendorong mereka untuk berwirausaha adalah faktor pendidikan formal dan pelatihan kewirausahaan yang pernah diikuti.

Faktor internal yang menghambat pengrajin sulaman berwirausaha adalah tugas-tugas sebagai ibu rumah tangga, masa kehamilan dan tugas menjaga anak. Sementara dari segi emosional adalah kesulitan dalam mengambil keputusan karena terlalu banyak pertimbangan. Selain itu kondisi perasaan dan hubungan antara lakilaki dan perempuan dalam sebuah usaha mengganggu konsentrasi mereka dalam berbisnis. Untuk faktor eksternal faktor sosial budaya yang menghambat pengrajin wanita dalam berwirausaha adalah anggapan masyarakat bahwa yang mencari nafkah adalah kaum perempuan. Selain itu juga hambatan dari segi budaya mingkabau. Selain itu hambatan dari segi administrasi muncul dari sulitnya mendapatkan bantuan modal dan birokrasi yang berbelit-belit.

Penelitian yang mengkaji tentang kegiatan berwirausaha perempuan juga dilakukan oleh Novialdi dkk (2009). Berdasarkan hasil penelitiannya diketahui bahwa: (1) pengusaha perempuan makanan kecil Minangkabau siap untuk memasuki dunia bisnis sebagai wirausaha, (2) pengusaha perempuan makanan kecil Minangkabau mamasuki dunia bisnis secara ekonomis mampu memberikan kontrubusi pendapatan keluarga dan membuka lapangan pekerjaan masyarakat sekitarnya, tetapi berkurang waktunya melaksanakan fungsi-fungsi rumah tangga dan mengurus keluarganya, dan (3) untuk menyiapkan perempuan Minangkabau memasuki bisnis diperlukan strategi pengembangan berupa: peningkatan aset, 
pemasaran, peningkatan mutu SDM dan peningkatan pemahaman nilai kekeluargaan, adat dan keagamaan.

Dari dua penelitian di atas diketahui bahwa kegiatan kewirausahaan yang dilakukan perempuan tak kalah memegang peranan penting bagi kehidupan ekonomi mereka. Salah satu hal yang melatarbelakangi kaum perempuan untuk berwirausaha adalah karena suami yang merantau, perempuan yang memegang kendali harta ataupun karena melanjutkan usaha keluarga.

Adanya budaya merantau telah mengakibatkan banyak laki-laki Minangkabau yang pergi ke luar Sumatera Barat untuk belajar dan mencari pekerjaan. Kondisi ini mengakibatkan urusan mencari nafkah keluarga mulai banyak diambil alih oleh perempuan dan ditambah lagi adanya kecendrungan laki-laki Minangkabau di Sumatera Barat berkurang melakukan kegiatan yang produktif (berbeda dengan diperantauan) (Latif, 2002). Kondisi inilah yang menyebabkan keterlibatan perempuan Minang dalam sektor ekonomi meningkat baik dalam sektor formal maupun informal. Saat ini keterlibatan perempuan tersebut tidak hanya sebagai pekerja, tetapi juga ada kecenderungan bagi perempuan Minang mulai terlibatsebagai pengelola (menejer) pada bidang perdagangan dan industri kecil yang berupa industri keluarga.

Kemampuan kerja perempuan sebagai pengelola diduga akan lebih baik dibandingkan dengan pria. Hal ini disebabkan karena kecermatan perempuan dalam mengatur keuangan, kepekaan dan bisa mencari peluang yang lebih baik (misalnya: mensiasati keterbatasan modal, menemukan peluang pasar, dan lain-lain). Tetapi perempuan yang berperan di luar rumah seringkali masih mendapatkan hambatan, baik hambatan kultural maupun hambatan sosial dan ekonomi.

Keterlibatan perempuan di sektor publik, membawa dampak terhadap peranan perempuan dalam kehidupan keluarga. Di satu pihak, perempuan bekerja dapat berperan membantu ekonomi keluarga dan sebagai pencari nafkah utama dalam keluarga, disisi lain peranannya dalam urusan rumah tangga (domestik) menjadi berkurang karena lamanya waktu yang digunakan untuk aktivitas di luar rumah tangga (publik).

\section{PENUTUP}

Kedudukan dan peranan perempuan di Minangkabau di Sumatera Barat dapat dilihat dari dua segi. Pertama, masyarakat itu mampu bertahan dan mempertahankan nilai-nilai kebudayaannya. Kedua, perempuan sebagai pemegang amanah dalam melindungi dan mewujudkan kesejahteraan masyarakat. Berdasarkan beberapa temuan penelitian yang telah dilakukan, cukup banyak perempuan yang sukses menjadi wirausahawan walaupun juga terkendala oleh berbagai hal. Aktivitas berwirausaha perempuan Minangkabau ini dilakukan salah satunya adalah untuk membantu perekonomian keluarga. Dari kegiatan usaha yang dilakukannya, disamping dapat membantu perekonomian keluarga sendiri, perempuan pengusaha Minangkabau juga dapat membantu pemerintah dalam menyediakan lapangan pekerjaan sehingga dapat meningkatkan taraf hidup masyarakat sekitarnya.

\section{DAFTAR PUSTAKA}

Abidin, Mas'oed. (2008). Sistem Kekerabatan Matrilineal. (Online). www.cimbuak.net. Diakses tanggal 7 Maret 2013. 
Alma, Buchari. 2009. Kewirausahaan untuk Mahasiswa dan Umum. Bandung. Alfabeta.

Armiati, 2010. Pengaruh Efikasi diri dan Hasil Belajar terhadap Minat Mahasiswa Membuka Usaha Melalui Motivasi Berwirausaha di Program Studi Pendidikan Ekonomi Universitas Negeri Padang. Tesis, Program Studi Pendidikan Ekonomi, Program Pascasarjana Universitas Negeri Malang.

Bungo, Nelmawarni dan Hussin, Nordin. 2011. Merantau ke Kuala Lumpur: Tradisi merantau dan berdagang masyarakat Minang. Malaysian Journal of Society and Space. Special Issue: Social and Spatial Challenges of Malaysian Development (116 - 131) (C) 2011, ISSN 2180-2491.

Buttner, E. H. 1993. Female entrepreneurs: how far have they come? Business Horizons, 36 (Mar-April), 59-65.

Graves, Elizabeth E. (2007). Asal usul Minangkabau Modern - Respons terhadap Kolonial Belanda Abad XIX/XX. Terjemahan. Jakarta: Yayasan Obor Indonesia.

Hermayulis. (2000). Peranan dan Kedudukan Perempuan Melayu dalam Masyarakat Matrilineal Minangkabau di Sumatera Barat. http://www.ukm.my/ penerbit/sari.

Kaplin, E. (1988). Women entrepreneurs: constructing a framework to examine venture success and business failure. Wellesley, MA: Babson College.

Latif. C. N. 2002. Etnis dan Adat Minangkabau. Permasalahan dan Masa Depannya. Bandung: Angkasa.

Maharajo, Djanalis Djanaid, dkk. (2011). Manajemen dan Leadership dalam Budaya Minangkabau. Malang: UB Press.

Miko, Alfan. 1991. Pekerja Wanita pada Industri Rumahtangga Sandang di Propinsi Sumatera Barat. PPK-UGM. Yoyakarta

Novialdi, dkk (2009). Strategi Penyiapan Pengusaha Industri Makanan Ringan Perempuan Minangkabau. Jurnal Agribisnis kerakyatan vol. 2 no. 1 Mei$\underline{2009}$.

Parasuraman, S., Y.S. Purohit, V.M. Godshalk, \& N.J. Beutell (1996). Work and family variables, entrepreneurship, career success and psychological wellbeing. Journal of Vocational Behavior, 48(3), 275-300.

Parker, Betty J. 2010. A Conceptual Framework for Developing the Female Entrepreneurship Literature. Journal of Research on Women and Gender, Maret, 169-190.

Rahmidani, Rose, dkk. (2012). Analisis Faktor Pendorong dan Penghambat Berwirausaha pada Pengrajin Sulaman Wanita di Jorong Lundang Kanagarian Panampuang Kab. Agam. Laporan Penelitian DIPA UNP.

Raman, Kavitha dkk. 2008. Motivational Factors Affecting Entrepreneurial Decision: A Comparison between Malaysian Women Entrepreneurs and Women Non Entrepreneurs. Journal of Communication of IBIMA vol 2, 8589.

Riyanti, Benedicta, Prihatin, Dwi. 2003. Kewirausahaan dari Sudut Pandang Psikologi Kepribadian. Jakarta: Grasindo.

Scott, C.E. (1986). Why More Women Are Becoming Entrepreneurs. Journal of Small Business Management, 24(4), 37-44.

Sinhal, Shalini (2005), "Developing Women Entrepreneurs in South Asia: Issues, Initiatives and Experiences", ST/ESCAP/2401, Trade and Investment 
Division, Bangkok: UNESCAP

Suryana. 2001. Kewirausahaan. Jakarta: Penerbit Salemba Empat.

Zimmerer. 1996. Entrepreneurship The New Venture Formation. Prentice Hall International, Inc. 